\title{
Biochemical Composition and Defensible Bioethanol Production from Seaweed Plentifully Available from Coastal Area of Saurashtra, Gujarat
}

\author{
Hardik B Bhatt ${ }^{*}$, Ridhdhi K Karangiya ${ }^{2}$ and Gayatri Prasad ${ }^{2}$ \\ ${ }^{1}$ OM College of Science \& P G Center, Junagadh - 362310, (Guj.) India, ${ }^{2}$ OM College of Science, Junagadh - 362310, (Guj.) India, ${ }^{2}$ P.G. \\ Department of Chemistry, Govt. P.G. College, Sirohi - 307001 (Raj.) India.
}

\begin{abstract}
Acanthophora spicifera (Red algae) and Dictyopteris australis (Brown algae), biomasses were pretreated and subjected to fermentation. Acid pretreatment yielded $35.82 \pm 0.12 \mathrm{mg} / \mathrm{g}$ and $28.04 \pm 0.09 \mathrm{mg} / \mathrm{g}$ of reduced sugar respectively. Acid pretreated biomass subjected to enzyme hydrolysis yielded $216 \mathrm{mg} / \mathrm{g}$ and $187 \mathrm{mg} / \mathrm{g}$ of reduced sugar. Separate hydrolysis and fermentation was carried out for acid hydrolysate using yeast strain isolated from cashew fruit juice (CJY) and toddy juice (TJY) hydrolysate with CJY strain yield $137 \mathrm{mg} / \mathrm{g}$ and $107 \mathrm{mg} / \mathrm{g}$ respectively of ethanol and TJY yielded $240 \mathrm{mg} / \mathrm{g}$ and $190 \mathrm{mg} / \mathrm{g}$ respectively for A. spicifera and D. australis of ethanol achieving 26.4 and 20.6 and $47.8 \%$ and $37.4 \%$ theoretical efficiency respectively in SHF process. In SSF process, TJY yielded higher ethanol yield of $470 \mathrm{mg} / \mathrm{g}$ and $370 \mathrm{mg} / \mathrm{g}$, achieving $84.2 \%$ and $73.7 \%$ theoretical efficiency and exhibiting thermo tolerance ability.
\end{abstract}

Keywords: Acanthophora spicifera (Red algae) and Dictyopteris australis (Brown algae), Bioethanol, SHF, SSF, Thermo tolerance.

\section{Background}

Non-renewable fossil fuels triggered serious environmental influence because of that renewable and sustainable energy sources have come into existence (1). Deteriorating fossil fuel has stood intimidation to global economy. An overwhelming increase in the demand for fuel is just because of Population explosion together with increased motorization (2). To improve the environment, bioenergy is an auspicious solution for energy, food and environment problem for the nations which are coal dependent presently and in urgent need of alternative fuels to secure their future (3).

1st Generation biofuel was bioethanol from sugar and starch (sugar cane, maize, corn, sugar beet). Conversely, huge scale production of this biomass harms the environment by the use of dangerous pesticides, and valuable resources like arable land and enormous quantities of water. World's largest bioethanol renewable resources belonging to 2nd generation biofuel that was bioethanol from lignocellulosic feedstock like industrial and agriculture residue (barley straw, newspaper, and cotton). Biofuel produced using lignocellulosic biomasses originate from agricultural and forest residues (4). However, obstacles in lignocellulosic biomass for conversion to biofuels are cost intensive pretreatment processes due to the presence of lignin molecule. Sustainability of first and second generation biofuels is questioned in connection with food versus fuel argument, carbon accounting

*Address of Correspondence: Dr. Hardik B Bhatt. Affiliation: OM College of Science \& P G Center, Junagadh 362310, (Guj.), India. Email address: bhatthardik_msc@yahoo.com (Received 09 August 2020; revised 30 August 2020; accepted 08 September 2020) 
and land use (5). Therefore, algae are considered as 3rd Generation feedstock for biofuel production. Advantages of algal biomass over first and second generation feedstock's are low land requirement for biomass production and highoil content with high productivity (6).

Aquatic plant (algae) divided into two different groups, micro and macro algae. As the seaweeds do not have lignin at all, the conversion of carbohydrate into ethanol does not require delignification process. As per the characteristics study of seaweeds they are found as the major source for production of bioethanol (7). The production of high concentrations of ethanol from seaweeds requires the conversion of every major carbohydrate into ethanol. In order to produce bioethanol from seaweeds in a cost-effective manner, microorganisms that possess the ability to directly convert polysaccharides (including glucans) into ethanol must be screened or constructed (8).

Microalgae are unicellular found in sea or freshwater ranging from milli to nanometers in size. Macroalgae do not have root, stem, or leaflike macro algae or other aquatic plants, but macro algae or otherwise known as seaweed are found in fresh, or saline water. They are aquatic plants of 50-60 m (9).

Macroalgae are preferred due to its high growth rate, minimum utilization of freshwater and low amount of lignin, allowing efficient processing. Cultivation of macroalgae requires inshore water rather than agricultural land providing a low cost for bioethanol production (10).

According to the specific combination of photosynthetic pigments, they can be classified into three groups: green (Chlorophyta, mainly chlorophyll A and B), brown (Phaeophyceae, mainly chlorophyll $A$ and $C, \beta$ - carotene and xanthophylls) and red algae (Rhodophyta, mainly chlorophylla, phycoerythrin and phycocyanin) (11).

Red seaweeds are mostly utilized for extraction of carrageenan and agar, whereas alginates are extracted from brown seaweeds. The left over residues rich in cellulose are utilized for biofuel production. Green seaweeds are mostly used for food purpose in Southeast Asian countries (12). Wild strains have ability to convert the seaweed sugars to bioethanol. Highest ethanol yield of $0.31 \mathrm{~g} / \mathrm{g}$ was obtained for TY strain during SSF process (18). Bioethanol has been obtained from all the three types of algae; however study indicates Laminaria japonica, Eucheuma spp., Kappaphycusalvarezii, Undariapinnatifida, and Gracilariaverrucosa as the most promising feedstocks for biorefinery (13).

In India, bioethanol potential from red seaweed species Kappaphycus alvarezii (14), Gracilaria verrucosa (15) and Gracilaria corticata and green seaweed species Ulva fasciata (16), Ulva lactuca (17) have been explored. Bioethanol production process for conversion of algal sugar to ethanol from macro algae involves three major processes such as pretreatment, saccharification and fermentation.

Pretreatment involves acid hydrolysis of the biomass, which alters the structural integrity of the biomass and release sugars. Acid pretreatment increases the accessibility of enzyme for saccharification process; enzymes hydrolyze the cellulose present in algal cell walls to mono saccharides (19). Sugars released after acidic and enzymatic hydrolysis are subjected to fermentation through yeast organism to produce bioethanol (20). Red algae biomass produces the highest amount of bioenergy as compare to other source of biomass (21).

This investigate explores the feasibility of two algae Acanthophora spicifera (Red algae) and Dictyopteris australis (Brown algae), as suitable feedstock for bioethanol production. Reducing sugar from both acid and enzyme hydrolysis were subjected to fermentation using wild yeast strains.

\section{Methodology Macroalgal sampling}

Two algae Acanthophora spicifera (Red algae) and Dictyopteris australis (Brown algae) were collected from the site Lat. and Long. 22.24 N, 68.97 E, Beyt Dwarka, District Devbhumi Dwarka, Gujarat, India, 361350 during low tide period in th e month of March - 2020 (Figure 1,2 and 3) (https://www.google.co.in/maps/place/Beyt+Dw arka,+Gujarat/@22.1408106,71.1329505,8z/data $=! 4 \mathrm{~m} 5 ! 3 \mathrm{~m} 4 ! 1 \mathrm{~s} 0 \times 3956 \mathrm{bca} 0 \mathrm{fbd} 18 \mathrm{f} 5 \mathrm{f}: 0 \times 624 \mathrm{~b} 9 \mathrm{fde} 4$ 0601bb9!8m2!3d22.4575896!4d69.1000033).

They were cleaned thoroughly by rinsing in the seawater to remove epiphytes, which were air-dried under shade and oven dried at $60{ }^{\circ} \mathrm{C}$ for $5 \mathrm{hrs}$ and pulverized using mortar and pestle, and then sieved to get powder of $<0.1 \mathrm{~mm}$. These samples were stored in air tight bags for further analysis. 


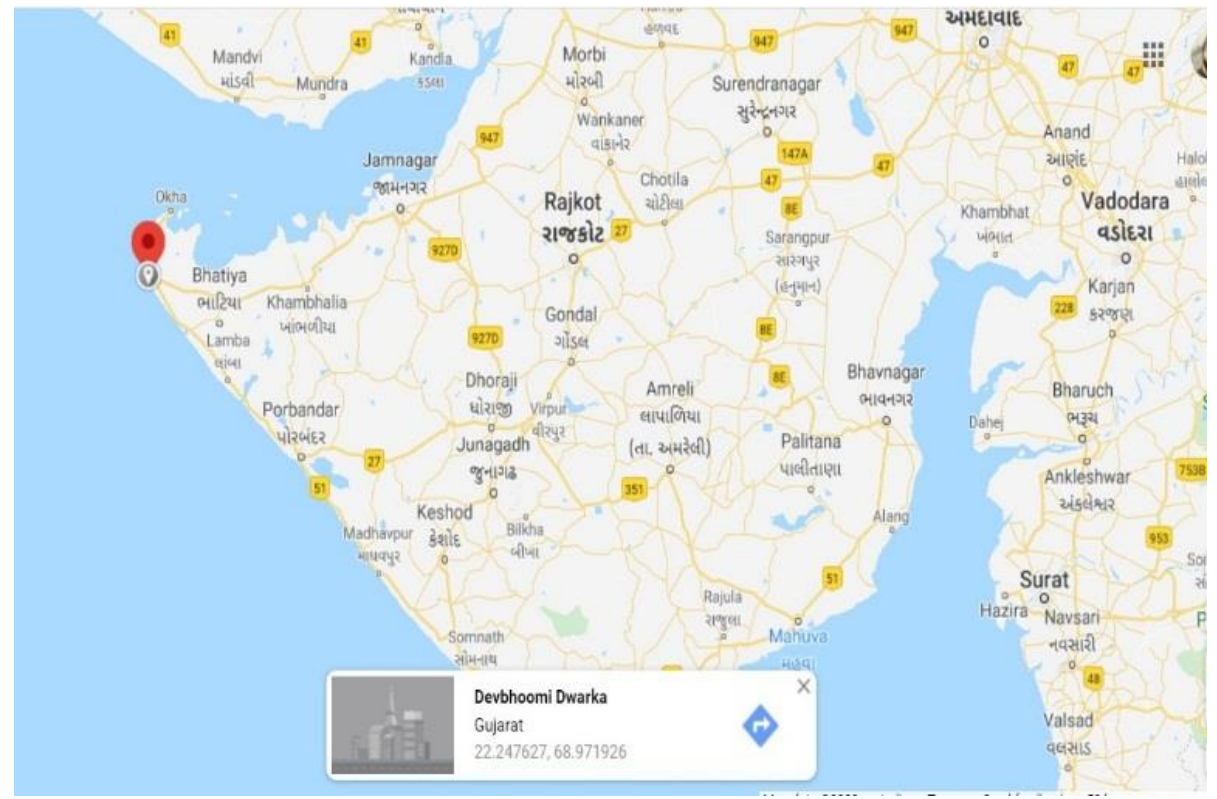

Figure 1

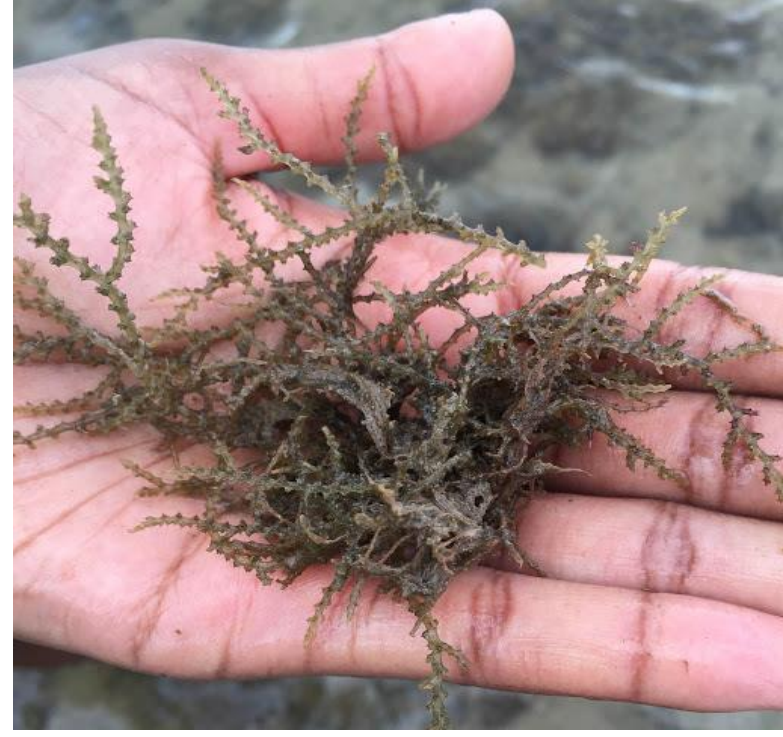

Figure 2: Acanthophora spicifera (Red algae)

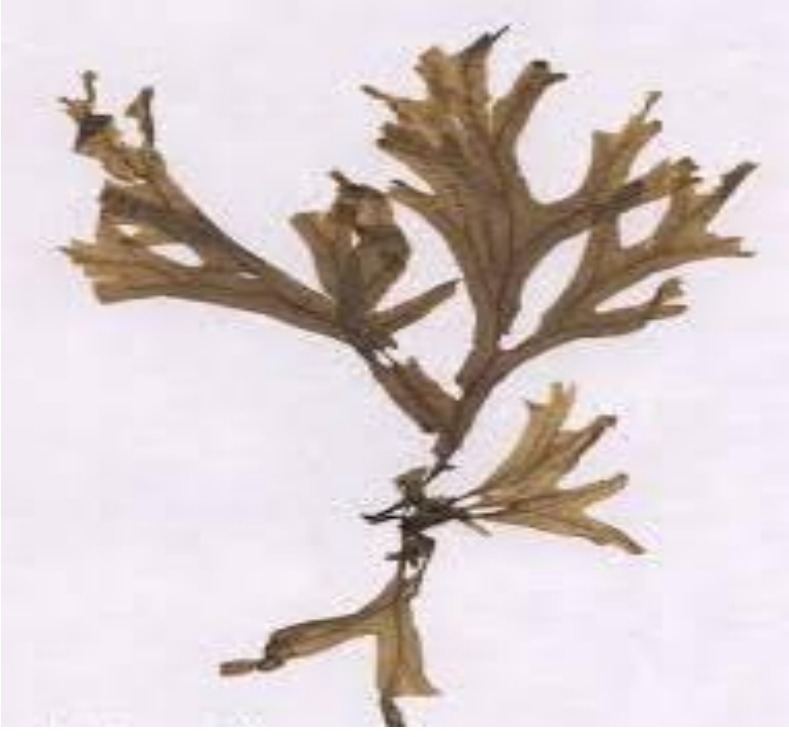

Figure 3: Dictyopteris australis (Brown algae)

\section{Systematic position}

Acanthophora spicifera (Red algae)

Division: Rhodophyta

Class: Rhodophyceae

Order: Ceramiales

Family: Rhodomeliaceae

Genus: Acanthophora

Species: Spicifera
Dictyopteris australis (Brown algae)

Division: Phaeophyta

Class: Pheophyceae

Order: Dictyotales

Family: Dictyotaceae

Genus: Dictyopteris

Species: Australis 


\section{Biochemical analysis}

Total carbohydrate analysis was performed by phenol-sulphuric acid method (22) followed by the determination of cellulose composition using anthrone reagent method (23). Protein content was estimated by Lowry's method (24). The experiment was performed in triplicates and the mean value was considered for further analyses.

\section{Pre-treatment process}

Acid hydrolysis: $100 \mathrm{mg}$ dried biomass was pretreated with $0.5 \mathrm{~N} \mathrm{H} 2 \mathrm{SO} 4$ at $121^{\circ} \mathrm{C}$ for $60 \mathrm{~min}$ to extract sugars. The hydrolysate was made up to $100 \mathrm{ml}$. After hydrolysis the hydrolysate was neutralize with $2 \mathrm{~N} \mathrm{NaOH}$ to acquire $\mathrm{pH} 6$. The preliminary reducing sugar concentration was calculated using DNS method.

Enzyme hydrolysis: Pretreated biomass was subjected to enzyme hydrolysis using enzyme (S9) extracted from marine bacteria. Enzyme hydrolysis was carried out at $55^{\circ} \mathrm{C}$ for $36 \mathrm{hr}$ and pH 6.8 (Potassium phosphate buffer). The sugar released was estimated every $6 \mathrm{hr}$ using DNS method.

\section{Yeast Isolation and Fermentation}

Yeast Isolation: Yeast were isolated from cashew fruit juice (CJY) and toddy juice (TJY) and plated on YEPDA medium of composition $20 \mathrm{~g} / \mathrm{L}$ peptone, $10 \mathrm{~g} / \mathrm{L}$ yeast extract, $20 \mathrm{~g} / \mathrm{L}$ dextrose, 15 $\mathrm{g} / \mathrm{L}$ agar. Yeast deferment was maintained at $35^{\circ} \mathrm{C}$ till OD 600 of 0.6 was achieved for further fermentation.

Ethanol fermentation: The hydrolysate obtained from acid pretreatment and enzyme pretreatment were subjected for fermentation using CJY and TJY. Separate hydrolysis and fermentation (SHF) was carried out where hydrolysate (obtained from acid pretreatment and enzyme hydrolysis) were inoculated with $6 \% \mathrm{v} / \mathrm{v}$ yeast seed culture $(0.6$ OD 600) and sealed with rubber flask to provide anaerobic condition, fermentation was carried out at $28{ }^{\circ} \mathrm{C}$ for $24 \mathrm{hr}$. concurrent Saccharification and Fermentation (SSF) was carried out using 2\% $(\mathrm{w} / \mathrm{v})$ pretreated biomass and $6 \%(\mathrm{v} / \mathrm{v})$ enzyme and yeast were added to the medium and fermented using $\mathrm{CJY}$ and $\mathrm{TJY}$ at $55^{\circ} \mathrm{C}$ for $24 \mathrm{hr}$.
The ethanol present in the fermented broth was analyze using GC-FID.

\section{RESULTS AND DISCUSSION}

\subsection{Characterization of Acanthophora spicifera and Dictyopteris australis}

During favorable nutrient, salinity, light and temperature condition they grow profusely and occupy intertidal zones. Both the algae were collected from Beyt Dwarka, Gujarat, during the low tide period. Ulva lactuca, green seaweed to enzyme hydrolysis and obtained $112 \mathrm{mg} / \mathrm{g}$ of reducing sugar (25). Complementary to dilute acid pretreatment shortcomings are enzyme hydrolysis which do not release inhibitors (26). Higher temperature shortens the exponential phase of the yeast cell resulting in reduced ethanol production (27).

The red macroalgae Acanthophora spicifera has potential bioactive sulfated polysaccharide. It contains galactose (73.5 \%), xylose (9.2\%), mannose (1.9\%), arabinose (10.9 $\%)$ total sugar $(63.3 \%)$ and total sulfate $(21.9 \%)$ (28). Spicifera has been identified as very complex as in sulfate. In the Brown algae - Dictyopteris australis, some species show a distinct photochemistry, with specific secondary metabolites, including C11-hydrocarbons, sulfur compounds and quinone derivatives, not usually found in marine seaweeds and described for the first time in the literature. Protein content, total sugar and fat contents ranged between $14.4 \%$ and $23.8 \%, 32.4 \%$ and $49.3 \%$ and $0.6-3.6 \%(29,30)$.

\subsection{Pretreatment}

\subsubsection{Dilute acid hydrolysis}

Dilute acid pretreatment is most widely used process for extraction of reducing sugars from biomass. However drawback of this is degradation of sugars in to inhibitors such as hydroxyl methyl furfural (HMF). Biomass treated using dilute acid yielded $35.82 \pm 0.12 \mathrm{mg} / \mathrm{g}$ and $28.04 \pm 0.09 \mathrm{mg} / \mathrm{g}$ of reducing sugar respectively. Pretreatment improves porosity of the biomass and decreases the crystallinity of the biopolymer cellulose. Complementary to dilute acid pretreatment shortcomings are enzyme hydrolysis which do not release inhibitors. Pretreatment of biomass is done to expose the cell constituents and cell wall materials for enzyme action. 


\subsubsection{Enzyme hydrolysis}

Enzyme hydrolysis was performed for acid pretreated Acanthophora spicifera and Dictyopteris australis, yielded $216 \mathrm{mg} / \mathrm{g}$ (Figure 4) and $187 \mathrm{mg} / \mathrm{g}$ (Figure 5), isolated cellulase enzyme from Cladosporium sphaerospermum and subjected Ulva lactuca, green seaweed to enzyme hydrolysis and obtained $112 \mathrm{mg} / \mathrm{g}$ of reducing sugar. Subjected hydro thermally pretreated E. in testinalis to enzyme hydrolysis using commercial enzymes Viscozyme L and Cellic CTec2 and obtained $20.1 \mathrm{~g} / \mathrm{L}$ of reducing sugar. Reduced sugar were seen to increase linearly with incubation period from 12 to $24 \mathrm{hr}$ ranging from $75 \mathrm{mg} / \mathrm{g}$ to $213 \mathrm{mg} / \mathrm{g}$, and decreased beyond $24 \mathrm{~h}$ to $116 \mathrm{mg} / \mathrm{g}$ for Acanthophora spicifera and for Dictyopteris australis RS increase linearly with incubation period from 12 to $24 \mathrm{hr}$ ranging from $62 \mathrm{mg} / \mathrm{g}$ to $185 \mathrm{mg} / \mathrm{g}$, and decreased beyond $24 \mathrm{~h}$ to $96 \mathrm{mg} / \mathrm{g}$. (17).

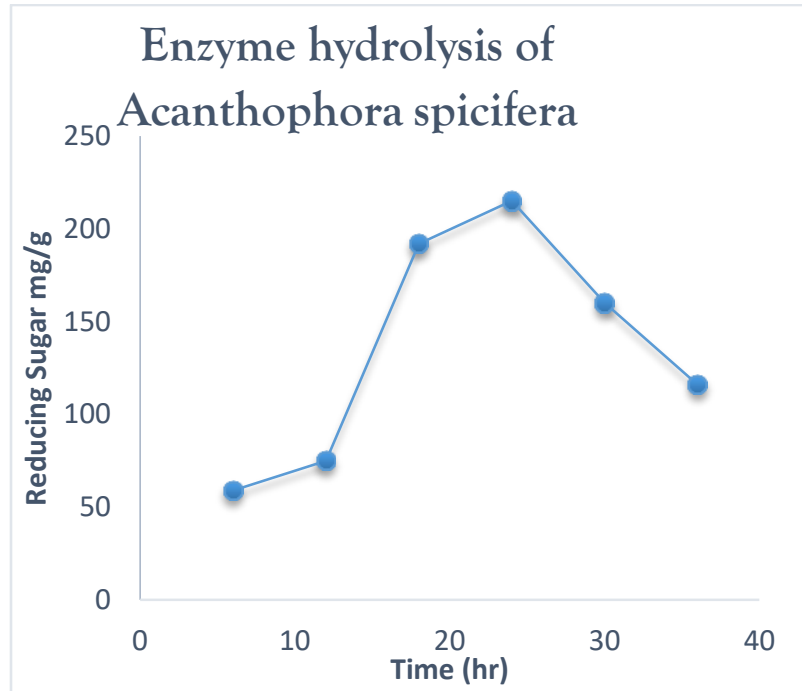

Figure 4

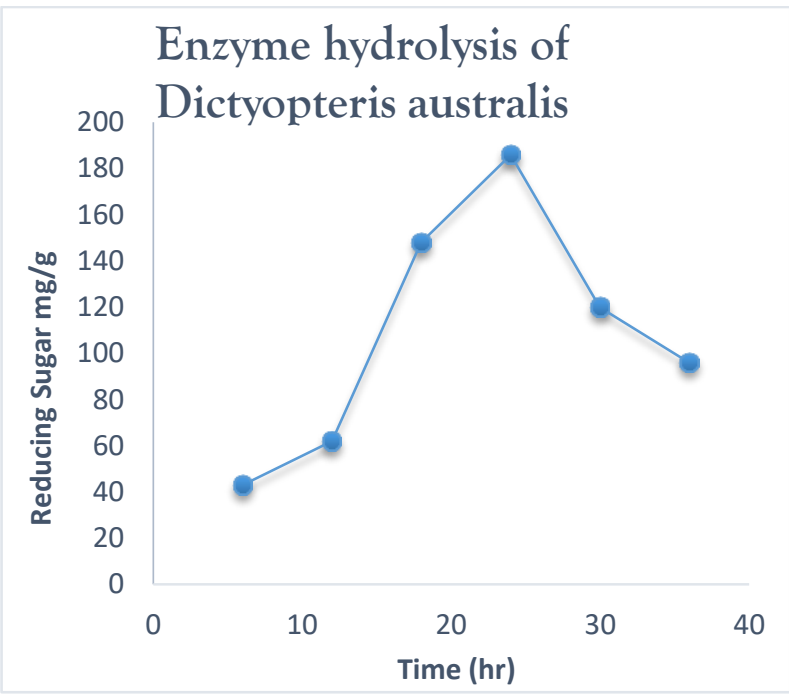

Figure 5

\subsection{Fermentation}

\subsubsection{Separate hydrolysis and Fermentation} (SHF)

Fermentation was carried out for Acanthophora spicifera and Dictyopteris australis by SHF method for 24h. Hydrolysate obtained from acid pretreatment was subjected to fermentation. Ethanol yield of $137 \mathrm{mg} / \mathrm{g}$ and $107 \mathrm{mg} / \mathrm{g}$ were obtained from $3.58 \mathrm{~g}$ and $2.80 \mathrm{~g}$ reducing sugar and theoretical efficiency of $26.40 \%$ and $20.65 \%$ respectively were achieved for hydrolysate with CJY strain (table 1). Hydrolysate with TJY strain yielded ethanol of $240 \mathrm{mg} / \mathrm{g}$ and $190 \mathrm{mg} / \mathrm{g}$ achieved from $3.32 \mathrm{~g}$ and $2.60 \mathrm{~g}$ reducing sugar and theoretical yield of $47.81 \%$ and $37.44 \%$ efficiency were achieved. TJY strain yielded higher efficiency than CJY strain indicating its potential in producing ethanol from seaweed.

\subsubsection{Simultaneous Saccharification and Fermentation (SSF)}

Higher ethanol yield were observed in SSF for ASTJY $470 \mathrm{mg} / \mathrm{g}$ and for DATJY $370 \mathrm{mg} / \mathrm{g}$ whereas for ASCJY $210 \mathrm{mg} / \mathrm{g}$ and for DACJY $160 \mathrm{mg} / \mathrm{g}$ of ethanol yield were recorded (Table 1). SSF operated at higher temperature of $55^{\circ} \mathrm{C}$ as enzyme gets activated at this temperature. TJY strain exhibited tolerance to higher temperature and yielded higher ethanol.

\subsection{Other value added properties of selected plants}

Acanthophora spicifera, have anticoagulant and antiplatelet. A. spicifera and commercial products inhibited aggregation of platelets and coagulation of plasma, and thus they have anti hemostatic properties (30).

Research on the Dictyopteris species, hundreds of metabolites have been isolated, includeing many unique molecules, such as uncommon sulfur compounds and meroditerpenes, which were reported for the first time. The biological activities reported to some Dictyopteris species suggest them to have a high medicinal potential (31). 
Table 1: Estimation of ethanol

\begin{tabular}{|c|c|c|c|c|c|c|c|}
\hline Process & Substrate & $\begin{array}{c}\text { Initial } \\
\text { Sugar } \\
(\mathbf{g} / \mathbf{L})\end{array}$ & $\begin{array}{c}\text { Final } \\
\text { Sugar } \\
(\mathbf{g} / \mathbf{L})\end{array}$ & $\begin{array}{c}\text { Fermented } \\
\text { Sugar } \\
(\mathbf{g} / \mathbf{L})\end{array}$ & $\begin{array}{c}\text { Ethanol } \\
(\mathbf{g} / \mathbf{L})\end{array}$ & $\begin{array}{c}\text { Ethanol } \\
\text { Yield } \\
(\mathrm{g} / \mathbf{L})\end{array}$ & $\begin{array}{c}\text { Theoretical } \\
\text { Yield (g/L) }\end{array}$ \\
\hline \multicolumn{8}{|c|}{ Estimation of ethanol Acanthophora spicifera } \\
\hline \multirow{2}{*}{ SHF } & EI CJY & 3.58 & 0.88 & 2.69 & 0.237 & 0.137 & 26.40 \\
\cline { 2 - 8 } & EI TYJ & $\mathbf{3 . 3 2}$ & $\mathbf{1 . 1 9}$ & $\mathbf{2 . 1 2}$ & $\mathbf{0 . 3 3 9}$ & $\mathbf{0 . 2 4}$ & $\mathbf{4 7 . 8 1}$ \\
\hline \multirow{2}{*}{ SSF } & EI CJY & 14.92 & 2.61 & 12.30 & 1.73 & 0.21 & 42.35 \\
\cline { 2 - 8 } & EI TYJ & $\mathbf{1 5 . 1 8}$ & $\mathbf{4 . 3 0}$ & $\mathbf{1 0 . 8 7}$ & $\mathbf{3 . 4 1}$ & $\mathbf{0 . 4 7}$ & $\mathbf{8 4 . 2 6}$ \\
\hline \multirow{2}{*}{ SHF } & EI CJY & 2.80 & 0.69 & 2.10 & 0.185 & 0.107 & 20.65 \\
\cline { 2 - 8 } & EI TYJ & $\mathbf{2 . 6 0}$ & $\mathbf{0 . 9 3}$ & $\mathbf{1 . 6 6}$ & $\mathbf{0 . 2 6 5}$ & $\mathbf{0 . 1 9}$ & $\mathbf{3 7 . 4 4}$ \\
\hline \multirow{2}{*}{ SSF } & EI CJY & 11.67 & 2.04 & 9.62 & 1.35 & 0.16 & 33.12 \\
\cline { 2 - 8 } & EI TYJ & $\mathbf{1 1 . 8 7}$ & $\mathbf{3 . 3 6}$ & $\mathbf{8 . 5 0}$ & $\mathbf{2 . 6 7}$ & $\mathbf{0 . 3 7}$ & $\mathbf{7 3 . 3 1}$ \\
\hline
\end{tabular}

\section{Conclusion}

Macroalgae is an attractive biomass for bioethanol production as they are rich in carbohydrates which can be readily converted to bioethanol using appropriate yeast microorganisms. Wild strains have ability to convert the seaweed sugars to bioethanol. Highest ethanol yield of $470 \mathrm{mg} / \mathrm{g}$ and $370 \mathrm{mg} / \mathrm{g}$ were obtained for TJY strain during SSF process indicating thermo tolerance nature of TJY strain.

Acanthophora spicifera and Dictyopteris australis are widely distributed along intertidal zones of bays and coastal ecosystem. Growth rate of Acanthophora spicifera and Dictyopteris australis reaches up to $3.60 \%$ and $7.80 \%$ per day.

Similarly, in Beyt Dwarka, District Devbhumi Dwarka, Gujarat, Acanthophora spicifera and Dictyopteris australis are recorded in large quantities along the intertidal zone during monsoon and post monsoon. Availability of such large biomass quantity can be tapped for bioethanol production

\section{References}

1 Srivastava N, Srivastava M, Mishra PK, Gupta VK, Molina G, Rodriguez-Couto S and Ramteke PW. Applications of fungal cellulases in biofuel production: Advances and Limitations. Renewable and Sustainable Energy Reviews. 2017.

2 John PR, Anisha GS, Nampoothiri and KM, Pandey A. Micro and macroalgal biomass: A renewable source for bioethanol. Bioresource Technol. 2011; 1: 186-193.
3 Qin Z, Zhuang Q, Cai X, He Y, Huang Y, Jiang D and Wang MQ. Biomass and biofuels in China: Toward bioenergy resource potentials and their impacts on the environment. Renewable and Sustainable Energy Reviews. 2017.

4 Ibrahim HAH. Pretreatment of straw for bioethanol production. Energy Procedia. 2012; 14: 542-551.

5 Araujo K, Mahajan D, Kerr R and Silva MD. Global biofuels at the crossroads: an overview of technical, policy, and investment complexities in the sustainability of biofuel development. Agriculture. 2017; 7(4): 32.

6 Kumar S and Sahoo D. Seaweeds as a source of bioethanol. Algal biotechnology and environment. IK International Publication, New Delhi. 2012; 101-109.

7 Behera S, Singh R, Arora R, Sharma NK, Shukla M and Kumar S. Scope of algae as third generation biofuels. Frontiers in bioengineering and biotechnology. 2015; 2: 90.

8 Mitsunori Y, Shigeyuki $\mathrm{K}$ and Kousaku M. Strategies for the production of high concentrations of bioethanol from seaweeds. Bioengineered. 2013; 4 (4):224-35.

9 Chamola R, Khan MF, Raj A, Verma M and Jain S. Response surface methodology based optimization of in situ transesterification of dry algae with methanol, $\mathrm{H} 2 \mathrm{SO} 4$ and $\mathrm{NaOH}$. Fuel. 2019; 239:511-520.

10 Per $\mathrm{G}$ and $\mathrm{W}$ Victoria. The development of seaweed-derived fuels in the UK: An analysis of stakeholder issues and public perceptions. Energy Policy. 2019; 133:110924.

11 Reviers B. Biologia e filogenia das algas. Translation: Iara Maria Franceschini.Artmed, Porto Alegre. 2006.

12 Hebbale D, Chandran MS, Joshi NV and 
Ramachandra TV. Energy and Food Security from Macroalgae. Journal of Biodiversity. 2017; 8(1): 111.

13 Jung KA, Lim SR, Kim Y and Park JM. Potentials of macroalgae as feedstocks for biorefinery. Bioresource technology. 2013; 135: 182-190.

14 Khambhaty Y, Mody K, Gandhi MR, Thampy S, Maiti P, Brahmbhatt $\mathrm{H}$ and Ghosh PK. Kappaphycus alvarezii as a source of bioethanol. Bioresource Technology. 2012; 103(1): 180-185.

15 Kumar A, Kumar K, Kaushik N, Sharma S and Mishra S. Renewable energy in India: Current status and future potentials. Renewable and Sustainable Energy Reviews, 2010; 14(8): 24342442.

16 Singh R, Srivastava $M$ and Shukla A. Environmental sustainability of bioethanol production from rice straw in India: a review. Renewable and Sustainable Energy Reviews. 2016; 54: 202-216.

17 Trivedi N, Reddy CRK, Radulovich R and Jha B. Solid state fermentation (SSF) - derived cellulase for saccharification of the green seaweed Ulva for bioethanol production. Algal Research. 2015; 9: 48-54.

18 Deepthi Hebbale and $\mathrm{T}$ V Ramachandra. Enteromorpha intestinalis as viable feedstock for bioethanol production. Lake Conference on Conservation and Sustainable Management of Riverine Ecosystems. The 11th Biennial Lake Conference. 2018.

19 Wei N, Quarterman J, and Jin YS. Marine macroalgae: an untapped resource for producing fuels and chemicals. Trends in biotechnology. 2013; 31(2): 70-77.

20 Trivedi N, Reddy CRK, and Lali AM. Marine microbes as a potential source of cellulolytic enzymes. In Advances in food and nutrition research. Academic Press. 2016; 79: 27-41.

21 Wi SG, Kim HJ, Mahadevan SA, Yang DJ and Bae HJ. The potential value of the seaweed Ceylon moss (Gelidium amansii) as an alternative bioenergy resource. Bioresource Technol. 2009; 100: 66586660.

22 Dubois M, Gilles KA, Hamilton JK, Rebers PT, and Smith F. Colorimetric method for determination of sugars and related substances. Analytical chemistry. 1956; 28(3): 350-356.

23 Updegraff DM. Semimicro determination of cellulose inbiological materials. Analytical biochemistry. 1969; 32(3): 420-424.
24 Lowry OH, Rosebrough NJ, Farr AL, and Randall RJ. Protein measurement with the Folin phenol reagent. Journal of biological chemistry. 1951; 193(1): 265-275.

25 Cho Y, Kim MJ, and Kim SK. Ethanol production from seaweed, Enteromorpha intestinalis, by separate hydrolysis and fermentation (SHF) and simultaneous saccharification and fermentation (SSF) with Saccharomyces cerevisiae. Korean Society for Biotechnology and Bioengineering Journal. 2013; 28(6): 366-371.

26 Jiang $\mathrm{R}$, Ingle $\mathrm{KN}$, and Golberg A. Macroalgae (seaweed) for liquid transportation biofuel production: what is next?. Algal Research. 2016; 14: 48-57.

27 Tesfaw A, and Assefa F. Current trends in bioethanol production by Saccharomyces cerevisiae: substrate, inhibitor reduction, growth variables, coculture, and immobilization. International Scholarly Research Notices. 2014.

28 Javee Anand, Malairaj Sathuvan, Gopal Venkatesh, Babu, Muthu Sakthivel, Perumal Palani, Subramani Nagaraj. Bioactive potential and composition analysis of sulfated polysaccharide from Acanthophora spicifera (Vahl) Borgeson. International Journal of Biological Macromolecules. 2014; 111: 1238-1244.

29 Dina Rodrigues, Ana C. Freitas, Leonel Pereira, Teresa A.P. Rocha-Santos, Marta W. Vasconcelos, Mariana Roriz, Luís M. Rodríguez-Alcalá, Ana M.P. Gomes, Armando C. Duarte. Chemical composition of red, brown and green macro algae from Buarcos bay in Central West Coast of Portugal. Food Chemistry. 2015; 183: 197-207.

30 Vivian Rodrigues de Souza, Laura de Andrade Moura, Ana Cláudia Rodrigues da Silva, Kelly Ketely Granja Pereira, Caio Cesar Richter Nogueira, Diana Negrão Cavalcanti, Valéria Laneuville Teixeira and André Lopes. Fuly Exploring the anticoagulant and antiplatelet effect of the extracts of the red marine algae Acanthophora spicifera. Journal of Medicinal Plant Research. 2018; 13(2): 31-40.

31 Gabriele Andressa Zatelli, Ana Cláudia Philippus, Miriam Falkenberg. An overview of odoriferous marine seaweeds of the Dictyopteris genus: insights into their chemical diversity, biological potential and ecological roles. Revista Brasileira de Farmacognosia. 2018; 28: 243-260. 